\title{
Power hop in agricultural tractors
}

\author{
José Fernando Schlosser ${ }^{1}$ (iD) Heliodoro Catalán ${ }^{2}$ (iD) Rovian Bertinatto ${ }^{2}$ iD \\ Marcelo Silveira de Farias $^{3 *}$ (D) Guilherme Dal Mas $^{4}$ (D) Mateus Cassol Cella ${ }^{4}$ (D)
}

\footnotetext{
${ }^{1}$ Departamento de Engenharia Rural (DER), Centro de Ciências Rurais (CCR), Universidade Federal de Santa Maria (UFSM), Santa Maria, RS, Brasil.

${ }^{2}$ Programa de Pós-graduação em Engenharia Agrícola (PPGEA), Universidade Federal de Santa Maria (UFSM), Santa Maria, RS, Brasil. ${ }^{3}$ Departamento de Ciências Agronômicas e Ambientais (DCAA), Universidade Federal de Santa Maria (UFSM), 98.400-000, Frederico Westphalen, RS, Brasil. E-mail: silveira_farias@hotmail.com. "Corresponding author.

${ }^{4}$ Curso de Engenharia Mecânica, Universidade Federal de Santa Maria (UFSM), Santa Maria, RS, Brasil.
}

ABSTRACT: The objective of this research was to develop concepts, possibilities of occurrence, and ways to solve the vibratory phenomenon of power hop, which is quite common in tractors with auxiliary front-wheel drive or all-wheel drive, in particular conditions of field work. First, the phenomenon is defined, and context is given for the practical situations in which the phenomenon can occur. Subsequently, actions are proposed to solve and minimize the problems arising from power hop. The subject of this study has been insufficiently analyzed in the literature, with mentions (some detailed) in scientific articles and theses developed to diagnose and propose ways to solve the problem. Equally, there has been almost no mention of the problem in agricultural tractor operation manuals, despite the frequent occurrence of the phenomenon. Key words: gallop, kinematic advance, auxiliary front-wheel drive.

O power hop em tratores agrícolas

RESUMO: $O$ objetivo deste trabalho foi desenvolver conceitos, possibilidades de ocorrência e modos de solucionar o fenômeno vibratório do power hop, bastante frequente em tratores com tração dianteira auxiliar ou tração integral, em condições particulares de trabalho em campo. Em um primeiro momento, o trabalho preocupa-se em definir o fenômeno e contextualizar as situações em que ele pode produzir-se em situações práticas. Posteriormente, são propostas ações para solucionar e minimizar os problemas decorrentes do galope, como também é conhecido, em língua portuguesa e espanhola. A temática que envolve este estudo é analisada de forma insuficiente pela bibliografia, encontrando-se menções, algumas detalhadas, em artigos cientificos e teses desenvolvidas com objetivo de diagnosticar e propor maneiras para solucionar o problema. Igualmente, é quase inexistente a menção do problema em manuais de operação de tratores agrícolas, em contradição com a frequente ocorrência do fenômeno.

Palavras-chave: galope, avanço cinemático, tração dianteira auxiliar.

One of the most important challenges in adapting high-powered tractors, with auxiliary frontwheel drive (FWD) or all-wheel drive, to fieldwork is the power hop phenomenon. According to LINARES et al. (2006), because of the rigid transmission of the tractor and the terrain, the tires or the FWD clutch coupling normally act as fuse elements. However, there are times when the differences are so great that the fuses are not enough, and the tractor starts to suffer from the phenomenon of energy accumulation, with consequent vibration.

Power hop is an example of self-excited vibration, characterized as a type of jump or oscillation, which alternates up and down movements in sequence, in the direction of the movement of tractors equipped with tires, resembling the galloping movement of a horse (WILEY \& TURNER, 2008).

When referring to the phenomenon of power hop (wind-up), RACKHAM \& BLIGHT (1985) defined it as the interference between two wheels of different diameters, rigidly connected to the same power transmission source, maintaining contact with the surface of the terrain and forced to spin at the same speed. The differences in size occur for several reasons, including the dynamic distribution of the mass on the axles, internal pressures of the tires, wear, and particular characteristics of the wheelsets. When the dynamic spokes in traction working conditions are not the same, the peripheral speeds of the driving wheels are affected, resulting in the occurrence of the power hop phenomenon and causing severe tire wear. 
This phenomenon generally occurs when the tractor is pulling implements or agricultural machines connected to the drawbar, on firm soils and in field operations with medium to high effort. This is commonly observed in auxiliary FWD, where the driving front wheels have a smaller diameter than the rear ones, but it can also occur in tractors with isodiametric all-wheel drive $(4 \times 4)$.

From the beginning of the occurrence of power hop, the tractor exhibits an oscillatory movement with gradually increasing amplitude until the driver is forced to intervene to maintain control of the machine. The amplitude of the oscillation increases with each cycle until it reaches a stable value, called the "limit cycle," determined by geometric restrictions or the power limits being applied. If it is not restricted early on, the movement makes driving impractical, becoming so severe that the operator may lose contact with the seat and controls, in addition to the possibility of component breakage or accidents.

The dynamic mass distribution, i.e., the mass transfer from the front to the rear axle, also influences the occurrence of power hop, with the variation of this mass transfer being a function of an external effort or force. As an example, when a tractor is pulling an implement to prepare the soil, which requires great traction effort, part of the mass of the tractor is transferred to the rear axle, causing a decrease in mass on the front wheels and;consequently, a greater tendency of these to slip, in addition to the deformation and diameter reduction of the rear wheels.

The greater the load fraction on the rear axle, the greater the deformation of the rear wheels. When this occurs and the kinematic relationship (KR) between the axles is altered, the front wheels acquire greater speed. Provided they have good grip with the ground, they transfer mass and traction to the front axle, causing a small jump and generating the start of the power hop. If there is excess ballast on the tractor, an even greater transfer of mass to the rear axle may occur, which can aggravate the power hop oscillations, if these are already occurring for other reasons.

Another important point regarding power hop is the type of soil and terrain where the work is being carried out because they are directly linked to the traction capacity and slippage index of the tractor. Normally, power hop occurs in dry soils and paved terrain because slippage is less on these types of terrains. Power hop is unlikely to occur in humid soils because the slippage between the wheels tend to increase, which softens the difference between the axes. This factor individually does not cause power hop to occur. The influence of one of the other factors previously mentioned is needed.

As power hop is a phenomenon that depends on several factors for its occurrence and solution, the option selected to solve the problem in a given situation may be ineffective in another because the machine and soil conditions are different. A sequence of activities to be developed, from the easiest to the most complex, to identify and solve the problem is shown in Figure 1.

There are some procedures that can be performed to correct the power hop problem. The first and simplest is the verification of the internal configuration and pressures of the tractor tires, respecting the recommendation of the manufacturer. There is a possibility to change this configuration by decreasing the pressure of the front tires and increasing that of the rear tires, which can be in reverse order, depending on the initial conditions presented and the KR. There are no fixed values of internal pressure that solve the problem in all cases.

If the problem persists, individual weighing of the tractor axles must be carried out to verify the static mass distribution. Tractors with auxiliary FWD should have a ratio close to $60 \%$ of the static mass on the rear axle and $40 \%$ on the front axle (FERREIRA et al., 2000) or, for modern tractors, approximately $55 \%$ on the rear axle and $45 \%$ on the front axle (MÁRQUEZ, 2012). Normally, when power hop occurs, there is more mass on the rear axle, which must be corrected with the addition of ballast on the front axle, successively, until the problem is resolved. If it is still not resolved, the mass on the rear axle should be reduced to balance the system.

If these first interventions are insufficient, the user must check the KR value between the front and rear axles of the tractor. Should the obtained value be more than the recommended one (greater than $5 \%$ ), it is necessary to decrease the internal pressure of the front axle tires and increase the pressure of the rear ones, repeating the KR calculation until the appropriate values are obtained.

It is also recommended that the user measure the slipping index of the tires because it is an indicator of the need for ballasting. As a reference, the values of 10 to $20 \%$ of slippage, depending on whether the tire structure type is radial or diagonal, should be sought to determine the amount of ballast because this range has the maximum efficiency in traction. 


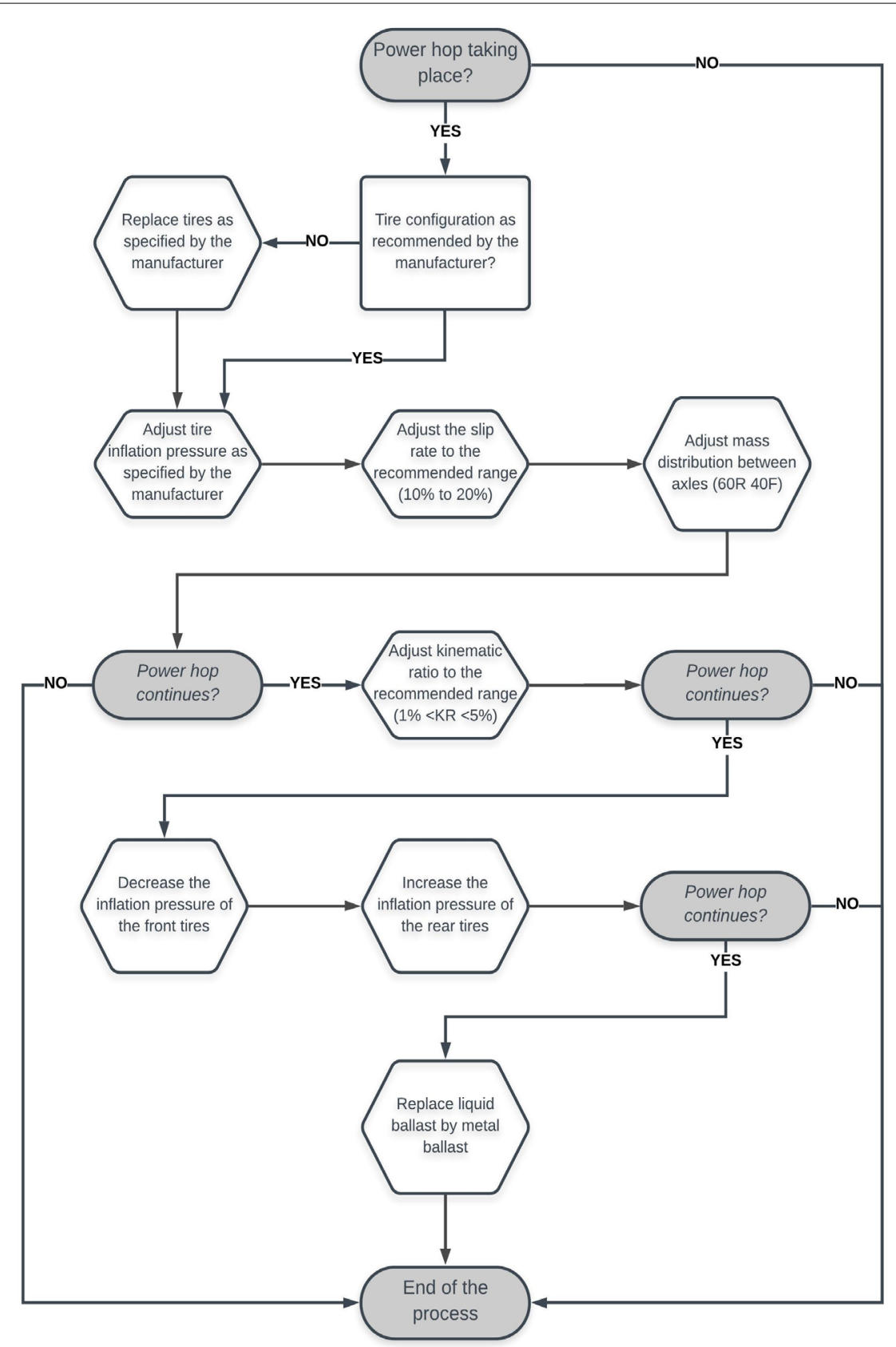

Figure 1 - Process flowchart for the power hop solution in FWD agricultural tractors.

\section{ACKNOWLEDGEMENTS}

This study was financed in part by the Coordenação de Aperfeiçoamento de Pessoal de Nível Superior - Brasil (CAPES) - Finance Code 001. The authors also grateful to the Conselho Nacional de DesenvolvimentoCientífico Tecnológico $(\mathrm{CNPq})$ for research productivity scholarship of the first author and scientific initiation scholarships; to the
Fundação de Amparo à Pesquisa do Estado do Rio Grande do Sul (FAPERGS).

\section{DECLARATION OF CONFLICT OF INTERESTS}

The authors declare no conflict of interest. The founding sponsors had no role in the design of the study; in the

Ciência Rural, v.50, n.8, 2020. 
collection, analyses, orinterpretation of data; in the writing of the manuscript, and in the decision to publish the results.

\section{AUTHORS' CONTRIBUTIONS}

The authors contributed equally to the manuscript.

\section{REFERENCES}

LINARES, P.; CATALÁN, H.; MÉNDEZ, V. Teoria de la tracción de tractores agrícolas. Universidad Politécnica de Madrid. Escuela Técnica Superior de Inginieros Agrónomos. Madrid, 2006. 215p.

MÁRQUEZ, L. Tractores agrícolas: tecnología e utilización. Madrid: B\&H Grupo Editorial, 2012. 844p.
RACKHAM, D.H.; BLIGHT, D.P. Four-wheel drive tractors - A review. Journal of Agricultural Engineering Research, v.31, n.3, p.185-201, 1985. Available from: <https://doi.org/10.1016/00218634(85)90087-3>. Accessed: Mar. 05, 2020. doi:10.1016/00218634(85)90087-3.

FERREIRA, M. F. et al. Kinematic relation on radial tires in a front wheel assist tractor on traction efficiency. Ciência Rural, v.30, n.6, p.983-986, 2000. Available from: <http://dx.doi.org/10.1590/ S0103-84782000000600010>. Accessed: Mar. 05, 2020. doi: 10.1590/S0103-84782000000600010.

WILEY, J. C.; TURNER, R. J. Power Hop Instability of Tractors. ASABE. Distinguished Lecture Series - Power Hop Instability of Tractors. 2008. 